\section{Selected Manifestations of Discrimination as Perceived by Male Employees in Polish Companies: A Self-Study Research Account ${ }^{1}$}

\author{
Bartłomiej Zinczuk \\ Faculty of Economics \\ Maria Curie-Sktodoroska University in Lublin, Poland \\ b.zinczuk@poczta.umcs.lublin.pl
}

Selected

Manifestations of Discrimination as Perceived by Male Employees in Polish Companies: A Self-Study Research Account

\begin{abstract}
Purpose - The purpose of the study was to estimate the prevalence of unequal treatment of men employed in Polish enterprises and the level of knowledge possessed by the employees in terms of the rights of discriminated persons.

Methodology - A survey was carried out using a survey questionnaire which included a total of 304 male employees in 12 surveyed enterprises, holding managerial and specialist positions, located in various functional areas of the organization.

Findings - The research confirmed the phenomenon of discrimination against men in the workplace and low level of respondents' knowledge on the rights of discriminated persons. The answers provided by male respondents show that the most frequently encountered type of discrimination in order of indication was discrimination on grounds of education, age, sex, while the least indicated kind of discrimination concerned disability.

Research implications - The findings of this study may serve as a starting point to discover the causes of the phenomenon of discrimination in the workplace.

Practical implications - The findings of this study may be used by employers to develop programs against discrimination and to educate employees in identifying and responding to cases of unequal treatment in the workplace.

Social implications - The findings of this study may increase the general knowledge on the phenomenon of discrimination in the workplace.

Originality/Value - The article complements the knowledge on the selected manifestations of discrimination, the prevalence of unequal treatment of men in their working life and the level of knowledge possessed by the respondents in terms of the rights of discriminated persons.

Type of article - A research article.
\end{abstract}

Keywords - discrimination, unequal treatment, stereotypes, employee.

1 The paper was compiled on the basis of a study conducted in the framework of a research grant titled: "Competence potential of Selected Employees' Groups in the Context of Diversity Management in Innovative Companies" 2013/09/B/HS4/01307.

\title{
synergia
}

International Journal of Synergy and Research Vol. 5, 2016 pp. 103-112 
IJSR 5

\section{Discrimination and its characteristics}

Any action which denies equal treatment to particular individuals, in comparison with others, e.g. because of their membership in a particular social group, is considered as discrimination, on the other hand, discrimination's prevention consists of measures preventing behavior which denies or limits any person's right to equal treatment (Sozański, 2005). Discrimination manifests in differentiation and preferential treatment of certain people over others (Kadiresan and Javed, 2015). The occurrence of discrimination is determined by e.g. socio-cultural factors, actions of employers, legislation, and social and economic problems (ILC, 2011). In general, discrimination is characterized as biased behavior which encompasses not only these activities exerting negative impact upon members of other groups, but also those which show partial favoritism towards members of one's own group (Dovidio et al., 2010). The fact that modern forms of discrimination are subtle and inconspicuous in character, which leads to numerous difficulties both for conceptualization and measurement of the phenomenon, is noteworthy (Pager and Shepherd, 2008). Discrimination may take up various forms e.g. direct and indirect (Hajian and Domingo-Ferrer, 2013). Direct discrimination occurs when an individual is treated less favorably in comparison with the way another individual, in a similar situation, is, was, or would be treated. The difference in the treatment may stem from a particular characteristic feature of the former individual, encompassing one of the illicit differentiating criteria such as age, sex, race (ZawidzkaŁojek, 2013). Indirect discrimination denotes such an application of lawful criteria which results in the emergence of discrimination. This is an instance when e.g. an apparently neutral regulation, criterion or practice, results in a particularly unfavorable outcome for a certain group of people in comparison with others, unless such a regulation, criterion, or practice, is objective, legally grounded, and means to an end are proportional and necessary (Barcik and Wentkowska, 2008). For example, discrimination of employees with regards to financial remuneration. Seemingly, an employer grants awards and bonuses to all their employees. However, these may be available solely to those remaining at full disposal. Apart from the above-mentioned forms of the phenomenon, the literature of the subject mentions individual, institutional, and structural discrimination (Pincus, 1996). Individual discrimination emerges when unequal treatment occurs between individuals. Institutional discrimination emerges in cases when, on the level of an institution (a group) there exist guidelines or instructions resulting in one of the groups being in a worse situation than the other one. Structural discrimination manifests via legal, socio-economic, and political systems, and results in people belonging to a particular group experiencing social exclusion. Discrimination is a negative phenomenon due to the significant individual, social, legal and economic consequences that it entails. This is a very complex phenomenon which, if once initiated, often tends to exacerbate. One of the fundamental regulations of labor law is the prohibition of discrimination with regards to employment. Pursuant to labor law, employees should be treated equally in relation to establishing and terminating an employment relationship, employment conditions, promotion conditions, as well as access to training in order to improve professional qualifications, in particular regardless of sex, age, disability, race, religion, nationality, political beliefs, trade union membership, ethnic origin, creed, sexual orientation, 
as well as regardless of employment for a definite or indefinite period of time or full time or part time employment (Polish Labor Code, Art. 183a §1). Numerous reports indicate the occurrence of discrimination in workplaces. However, the number of cases when labor code is breached in developing and underdeveloped countries is much greater than in developed ones (Bilkis et al., 2010). The provisions concerning discrimination and its various forms have been present in Polish legislation for several decades, however, employees are poorly familiar with them. The subordinates mistakenly interpret the concept of discrimination and incorrectly perceive the symptoms of this phenomenon, while employers are struggling with the problem of selecting appropriate solutions and measures which should be used effectively in order to fulfill the statutory obligation to prevent any forms of discrimination in the workplace (Mazanowska, 2013). Antidiscrimination laws offer protection to employees who were mistreated because of their race, age, background or religion. However, undertaking legal action by the aggrieved requires discriminating practices to be documented (Pager, Western, 2012). Cases of unequal treatment of employees are usually difficult to document and prove. Instances of unlawful and unequal treatment frequently occur behind closed doors of the workplace, and usually there are no eye-witnesses to such affairs. In such cases, the victim of discrimination may only report on what they experienced in "he said, she said litigation" (Wencel, 2011). The consequences of discrimination are severe for both the individuals who experience it as well as for the employers. Discrimination carries serious implications for persons covered by this phenomenon in the form of deteriorating their physical and mental health. Prolonged stress of high intensity has a destructive effect on people. Discriminated individuals often experience malaise, loss of confidence, anxiety and neurotic states. Disorders affect private and business relationships arising from the deterioration of their mental condition. Victims of discrimination very often cast doubt on their professional competence what influences their low self-esteem limiting or preventing the execution of their tasks at work. The effects of discrimination borne by the employee result directly in the consequences borne by the employer. After a prolonged period of events that are negative for the psyche of the employee, he or she may become incapable not only of working in this particular institution but even of exercising his or her profession. The effect of deteriorated physical and mental health of the employee is being on a sick leave more frequently. If employers violate the principle of equal treatment in the workplace, they are exposed to serious consequences of their actions. The most common effects of discriminatory practices that affect the employer are: litigation costs and compensation payments to the affected persons, the costs of increased staff turnover, the costs of training new employees, the deterioration of relationships between employees, interpersonal conflicts negatively influencing the pace and quality of work, loss of corporate image and reputation on the labor market and among customers.

\section{Research methods}

The objective of the present study was to evaluate the frequency of male employees' unequal treatment in Polish companies as well as the extent of their familiarity with rights of the discriminated against. Results featured in the paper originate from a study
Selected Manifestations of Discrimination as Perceived by Male Employees in Polish Companies: A Self-Study Research Account 
IJSR 5

\section{Chart 1.}

Percentage of respondents who experienced discrimination in the workplace (on the grounds of sex, age, education, disability) during their professional career conducted in the framework of a research grant ${ }^{2}$ for faculty members of the Institute of Management, Faculty of Economics at the Maria Curie-Skłodowska University in Lublin. Primary research encompassed 12 companies located in Poland (2 large and 10 medium-sized) representing sales, production and services sectors. The selection of these companies was purposive (innovative companies) and resulted from premises of the grant. The study was conducted by means of a survey questionnaire ${ }^{3}$, and encompassed 304 men. The sample was not representative. The questionnaire addressed men employed in the studied companies. They occupied positions of managers and specialists in various areas of their organizations. The survey was conducted between January and December 2015. Research results were presented in tables and charts, and feature a detailed description.

\section{Discrimination in Polish companies in light of own research results}

One of the fundamental premises of democratic societies is equal treatment for all citizens and prevention of any form of unequal treatment. Labor market constitutes an area where discrimination is reported the most frequently. The question on whether respondents experienced discrimination in the workplace during their working lives was posed as the first in the questionnaire. Chart 1 presents respondents' answers with regards to the question. Results acknowledged the fact that they did experience the phenomenon.

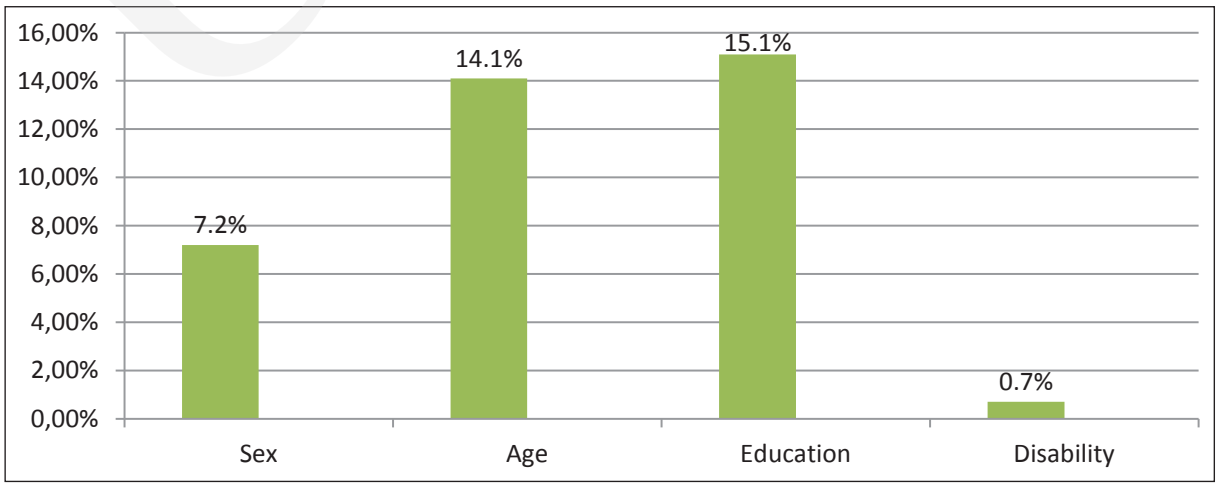

Source: Author's own study on the basis of research results; N=304.

2 Research grant titled 'Competence Potential of Selected Employees' Groups in the Context of Diversity Management in Innovative Companies” 2013/09/B/HS4/01307.

3 The paper utilizes one of eight parts constituting the survey questionnaire. The part in question was devoted to discrimination. 
Respondents' answers (Chart 1) indicate that the least frequent case of discrimination in the workplace is the one because of disability ( $0.7 \%$ of answers). Respondents' answers suggest that discrimination because of education $(15.1 \%)$, age (14.1\%) and sex $(7.2 \%)$ constitute the most frequent cases.

In the second question, respondents were requested to indicate whether they were discriminated against by being offered lower salaries because of stereotypes pertaining to sex, age, education and disability. Chart 2 presents distribution of respondents' answers to the second question.

Answers regarding being offered lower salaries because of stereotypes pertaining to age (Chart 2) indicated this form of discrimination as being the most frequent (18.8\% of answers). The second most frequent type of discrimination in the form of lower salaries being offered was motivated by stereotypes pertaining to education and was indicated by $15.1 \%$ of respondents. Stereotypes regarding sex motivated $9.2 \%$ of cases as far as salaries are concerned. Disability was indicated as the least frequent cause of this type of discrimination $(1.6 \%)$.

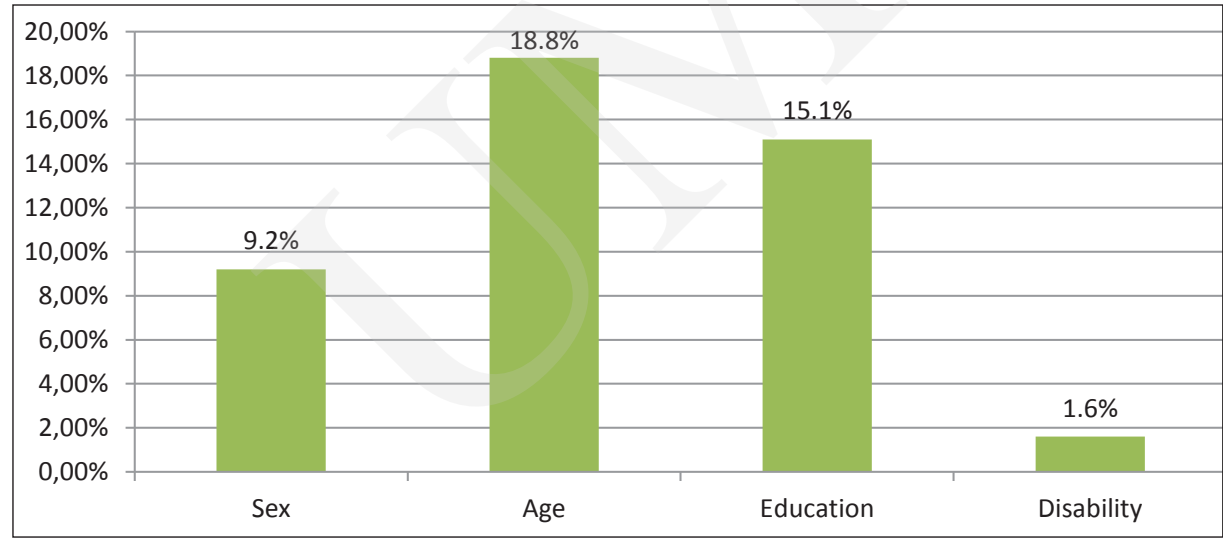

Source: Author's own study on the basis of research results; N=304.

The third question pertained to whether, in their working lives, respondents experienced their promotion opportunities being limited as a form of discrimination because of stereotypes pertaining to sex, age, education and disability. Chart 3 presents distribution of respondents' answers indicating cases of such discrimination.

The third question on having their promotion opportunities limited because of stereotypes pertaining to age (Chart 3 ) indicated this form of discrimination as the most frequent one (19.7\%). The second most frequent type of discrimination in the form of employees' promotion opportunities being limited was motivated by stereotypes pertaining to education (18.4\%). Discrimination because of sex scored third $(3.9 \%)$. Disability was indicated as the least frequent cause of this type of discrimination $(0.7 \%$ of proven cases).

The analysis of answers enables the following observation to be made. The most frequently selected answer regarding being offered lower salaries (Chart 2) and
Selected Manifestations of Discrimination as Perceived by Male Employees in Polish Companies: A Self-Study Research Account

Chart 2.

The respondents' answers, given as \%, confirming the cases of receiving lower remuneration by the employees as a manifestation of discrimination based on stereotypes concerning sex, age, education and disability 


\section{IJSR} 5

\section{Chart 3.}

Distribution of respondents' answers, given as $\%$, indicating cases of having their promotion opportunities limited as a form of discrimination because of stereotypes pertaining to sex, age, education and disability having promotion opportunities limited (Chart 3) because of stereotypes pertaining to age, results from bias against senior employees. Stereotypes concerning this group of employees result in them being perceived as worse than their younger colleagues. In light of studies examining senior and elderly employees, employers believe that seniors are characterized by the following: low level of education, low technical skills, low productivity, limited creativity, low adaptability to changing market conditions (Richert-Kaźmierska and Stankiewicz, 2013). Apart from the above-mentioned prejudices, the relatively strong competition between the senior and young on labor market ought to be taken into account. The generation of seniors (referred to as 50+) is frequently considered as "digitally excluded". This means that they lack proper motivation for applying IT tools at work. However, recent studies prove that senior employees are ready and willing to broaden their knowledge and IT skills, and they have become increasingly aware of this area as a vital element of vocational competences (Moczydłowska and Kowalewski, 2015). The fact that senior employees' knowledge, experience, and involvement in intra-organizational processes, inter-generational knowledge transfer, may be of key significance for modern organizations' functioning and development, ought to be highlighted.

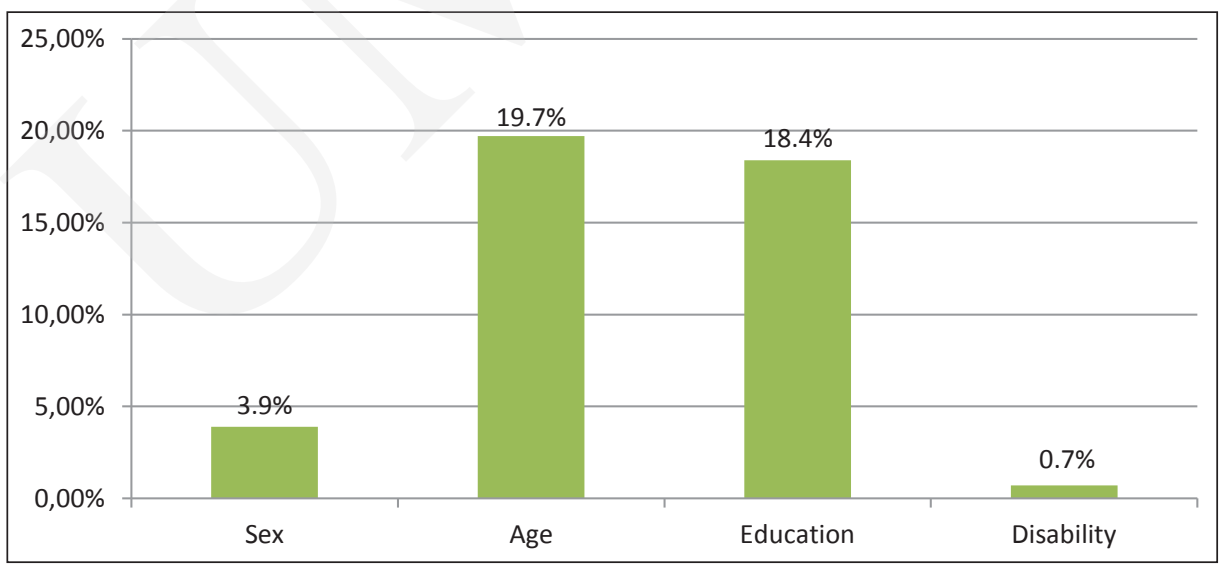

Source: Author's own study on the basis of research results; $N=304$.

The second most frequent answer pertained to cases of employees being offered lower salaries (Chart 2) and having their promotion opportunities limited (Chart 3) because of stereotypes associated with education. Respondents' answers may have been motivated by situations where men were discriminated against due to their education's level, or its incompleteness. At present, labor market features cases where it is not the incompleteness, but rather the level of education exceeding requirements of the position which poses a barrier for employment, promotion and remuneration.

The third most frequent case is associated with respondents' experience of being offered lower salaries (Chart 2) and having promotion opportunities limited (Chart 3) because of stereotypes pertaining to sex. The following observation can be made. 
Prejudices concerning men in a workplace occur less frequently than in case of women. As far as professional roles are concerned, there exist a number of stereotypes which present women much less favorably e.g. women are less effective in managerial positions, they are less decisive due to the sharing professional and familial roles.

In the course of the study, the research team devoted attention to the extent of respondents' familiarity with rights of the discriminated against. They were requested to indicate their knowledge of the issue. Distribution of answers is presented in Chart 4.

In total, $39.6 \%$ of all respondents indicated they were familiar with rights of the discriminated against very well and well. On the other hand, in total, $55 \%$ of men stated their knowledge of the issue was fair and poor. Complete ignorance with regards to the issue was declared by $5.4 \%$ of respondents. These results seem to acknowledge the fact that more than half of respondents, if faced with unequal treatment in a workplace, would be unable to enforce their rights. The probable reason behind such a deficit in the area lies in the insufficient involvement of employers in the process of educating employees with regards to identification of and response to any manifestation of discrimination in the workplace. Insufficient or a complete lack of knowledge concerning rights of the discriminated against translates directly into the quality and effectiveness of work of all employees of an organization.

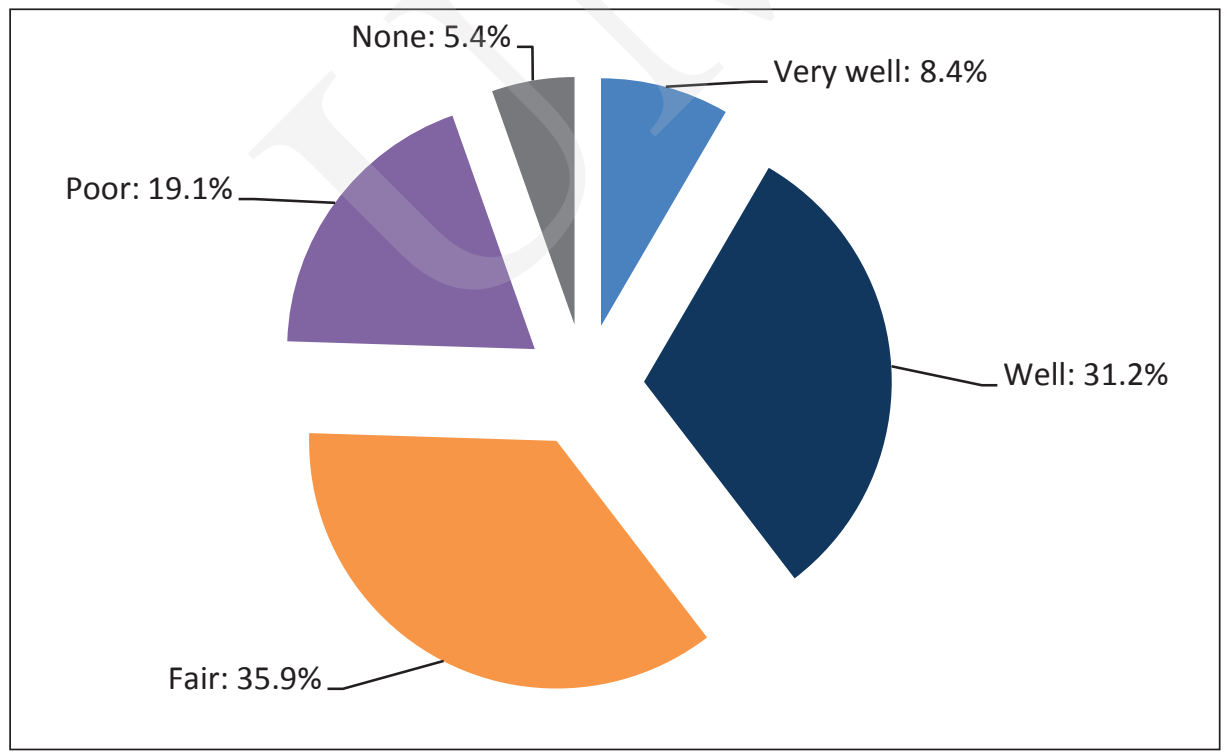

Source: Author's own study on the basis of research results; N=304.
Selected

Manifestations of Discrimination as Perceived by Male Employees in Polish Companies: A Self-Study Research Account

\section{Chart 4.}

Distribution of respondents' answers, given as $\%$, with regards to their familiarity with rights of the discriminated against 
IJSR 5

\section{Conclusions}

The following conclusions can be drawn on the basis of the survey conducted among male employees of Polish companies.

First of all, the presence of discrimination on Polish labor market was acknowledged. Prejudices with regards to sex, age, education and disability entail several hazards the discriminated against are exposed to in a workplace and outside. Breaking the stereotype depicting seniors as passive, unproductive, lacking initiative and unwilling to learn, constitutes a significant challenge targeting this particular employees' group. Contemporary stereotypes of elderly people influence the formation of specific attitudes and social responses: starting with hostility, through indifference, to compassion. They are perceived by older people as a sign of rejection, lack of social acceptance and restricting their rights as equal society members. The maintenance of such beliefs results in the deepening of age groups' polarization which in consequence may lead to a waste of potential inherent in the generational transmission. Similarly, promoting a positive image of senior employees as loyal, conscientious, meticulous and devoted to their workplaces, seems necessary. As a consequence, employers would be convinced that senior employees present a valuable asset. At present, prevention of discrimination because of age constitutes a critical element of labor market in many countries. Deficiency in labor force on labor markets of developed countries, as well as in Poland, ought to stimulate the emergence of policies and efforts preventing discrimination motivated by employees' age.

Secondly, respondents' low level of knowledge concerning rights of the discriminated against was proven. A recommended solution to the problem may be employers' education of employees as far as identification and prevention of discrimination in a workplace are concerned. Employers ought to play a leading part in the process. They are responsible for eliminating any unequal treatment and discrimination, as well as for preventing breaches of labor code in a workplace.

The article concerns the problem of discrimination against employees on account of their sex, age, education and disability during their working life which is a very current topic. It is worth emphasizing that there may also exist other forms of discrimination against employees in the place of employment - for example, on the grounds of race (Deitch et al., 2003), sexual orientation (Berg and Lien, 2002), religion (Vickers, 2010) and origin (Gee et al., 2006) - which are the object of interest and research of numerous scholars. The research results presented in the article should be a contribution to a meaningful discussion on the prevention and elimination of all discriminatory practices in the workplace. This is especially important in today's multicultural organizations whose members represent different social groups. Undertaken in the article research problem should be continued in the future research, due to determinants of organizational culture in the context of discrimination in the workplace. 


\section{References}

Barcik, J. and Wentkowska, A. (2008). Prawo Unii Europejskiej z uwzględnieniem Traktatu $z$ Lizbony (European Union Law Including the Treaty of Lisbon), C.H. Beck, Warsaw, p. 284.

Berg, N. and Lien, D. (2002). Measuring the Effect of Sexual Discrimination on Income: Evidence or Discrimination?, Contemporary Economic Policy, Vol. 20, No. 4, pp. 394-414.

Bilkis, A., Habib, S. B. and Sharmin, T. (2010). A Review of Discrimination in Employment and Workplace, ASA University Review, Vol. 4, No. 2, p. 137.

Deitch, E. A., Barsky, A., Butz, R. M., Chan, S., Brief, A. P. and Bradley, J. C. (2003). Subtle Yet Significant: The Existence and Impact of Everyday Racial Discrimination in the Workplace, Human Relations, Vol. 56, No. 11, SAGE Publications, pp. 1299-1324.

Dovidio, J. F., Hewstone, M., Glick P. and Esses, V. M. (2010). Prejudice, Stereotyping and Discrimination: Theoretical and Empirical Overview, The SAGE Handbook of Prejudice, Stereotyping and Discrimination, SAGE Publications LTD, London, p. 9.

Equality at work: The continuing challenge. Global Report under the follow-up to the ILO Declaration on Fundamental Principles and Rights at Work, (2011). International Labour Conference, 100th Session Report I(B) Geneva, p. 9. Retrieved from: http://www.ilo.org/ wcmsp5/groups/public/---ed_norm/---declaration/documents/publication/wcms_166583.pdf

Gee, G. C., Ryan, A., Laflamme, D. J. and Holt, J. (2006). Self-Reported Discrimination and Mental Health Status Among African Descendants, Mexican Americans, and Other Latinos in the New Hampshire REACH 2010 Initiative: The Added Dimension of Immigration, American Journal of Public Health, Vol. 96, No. 10, pp. 1821-1828.

Hajian, S. and Domingo-Ferrer, J. (2013). A Methodology for Direct and Indirect Discrimination Prevention in Data Mining, IEEE Transactions On Knowledge And Data Engineering, Vol. 25, No. 7, p. 1445.

Kadiresan, V. and Javed, N. K. (2015). Discrimination in Employment and Task Delegation at Workplace in the Malaysian Context, International Journal of Academic Research in Business and Social Sciences, Vol. 5, No. 7, p. 30.

Mazanowska, E. (2013). Pathologies of Motivation System - Reasons and Consequences, Contemporary Economy Electronic Scientific Journal, Vol. 4, No. 3, p. 31.

Moczydłowska, J. M. and Kowalewski, K. (2015). Stereotyp pracownika w wieku 50+ jako potencjalne źródło zachowań dyskryminacyjnych w środowisku pracy (The Stereotype of $50+$ Aged Employee as a Potential Source of Discriminatory Behavior in the Workplace), Modern Management Review, Vol. 20, No. 2, p. 73.

Pager, D. and Shepherd, H. (2008). The Sociology of Discrimination: Racial Discrimination in Employment, Housing, Credit, and Consumer Markets, Annual Review of Sociology, Vol. 34, p. 182.

Pager, D. and Western B. (2012). Identifying Discrimination at Work: The Use of Field Experiments, Journal of Social Issues, Vol. 68, No. 2, p. 221.

Pincus, F. L. (1996). Discrimination Comes in Many Forms: Individual, Institutional, and Structural, American Behavioral Scientist, Vol. 40, No. 2, p. 186.

Richert-Kaźmierska, A. and Stankiewicz, K. (2013). Kompetencje pracowników 55+ w opinii pracowników z młodszych grup wiekowych (Competencies of 55+ Aged Employees in the Opinion of Employees from Younger Age Groups), E-mentor, No. 1/48.

Sozański, J. (2005). Prawa człowieka $w$ systemach prawnych Wspólnot $i$ Unii Europejskiej (Human Rights in the Legal Systems of the Communities and the European Union), Polish Publisher Legal Iuris, Warsaw-Poznań, p. 198.

The Polish Labour Code, Art. 183a § 1.

Vickers, L. (2010). Religious Discrimination in the Workplace: An Emerging Hierarchy?, Ecclesiastical Law Society, Vol. 12, No. 3, pp. 280-303.
Selected Manifestations of Discrimination as Perceived by Male Employees in Polish Companies: A Self-Study Research Account 
IJSR 5
Wencel, K. (2011). Dowodzenie w sprawach o dyskryminację. Możliwości i ograniczenia udowodnienia nierównego traktowania (Proving in Cases of Discrimination. The Possibilities and Limitations of Proving Unequal Treatment), The Association for Legal Intervention. Analyses, Reports, Expertise, No. 7, p. 3.

Zawidzka-Łojek, A. (2013). Zakaz dyskryminacji ze względu na wiek w prawie Unii Europejskiej (Prohibition of Discrimination Based on Age in European Union Law), Instytut Wydawniczy EuroPrawo, Warsaw, p. 48. 